Małgorzata Świder

ORCID: 0000-0002-4354-3641

Uniwersytet Pedagogiczny im. KEN w Krakowie

\title{
Pytania o Polskę w okresie przełomu politycznego w 1989 roku w świetle relacji wybranych polityków zachodnioniemieckich
}

DOI: $10.19195 / 1643-0328.26 .13$

Słowa kluczowe: Okrągły Stół, Komitet Obywatelski, Solidarność, związki zawodowe, wybory czerwcowe w 1989, Republika Federalna Niemiec

\section{Wprowadzenie}

Sytuacja, jaka zaistniała w Polsce pod koniec 1988 roku, w szczególności zaś dynamicznie zachodzące wówczas przemiany, były przedmiotem analiz w Republice Federalnej Niemiec (dalej: RFN). Przygotowywali je zarówno politycy, jak i związkowcy, których interesował przede wszystkim rozwój sił opozycyjnych wobec rządu Wojciecha Jaruzelskiego, a także stan reform wewnętrznych. To zainteresowanie wynikało z przeświadczenia, że zawirowania polityczne i społeczne w Polsce mogły wpłynąć na kondycję relacji niemiecko-niemieckich, uzależnionych od pozytywnych relacji Wschód-Zachód. Chodziło głównie o stabilność sytuacji w ZSRR, a przede wszystkim o pozycję Michaiła Gorbaczowa i powodzenie pierestrojki ${ }^{1}$. O takiej zależności mówił w styczniu 1989 roku podczas spotkania z premierem PRL Mieczysławem Rakowskim ówczesny przewodniczący Socjaldemokratycznej Partii Niemiec (dalej: SPD) Hans-Jochen Vogel, porównu-

${ }^{1}$ O polityce ZSRR wobec Niemiec piszą m.in. A. Nepit, Die SED unter dem Druck der Reformen Gorbatschows: der Versuch der Parteiführung, das SED-Regime durch konservatives Systemmanagement zu stabilisieren, Baden-Baden 2004; T. Wagensohn, Von Gorbatschow zu Jelzin: Moskaus Deutschlandpolitik (1985-1995) im Wandel, Baden-Baden 2000; A. Gröss, Wandel der sowjetischen Osteuropa-Politik in der Ära Gorbatschow, Frankfurt am Main 1992; F. Oldenburg, Die Deutschlandpolitik Gorbatschows, 1985-1991, wyd. 17, Bundesinstitut für Ostwissenschaftliche und Internationale Studien, Köln 1992. 
jąc postępy reform w Polsce i pierestrojkę do bliźniaków syjamskich². Dla polityków zachodnioniemieckich, w tym przede wszystkim dla socjaldemokratów, ważne było utrzymanie się przy władzy Gorbaczowa, z którym wiązano duże nadzieje polityczne (w kontekście Ostpolitik). Umocnienie jego pozycji mogło ukazać słuszność kursu reformatorskiego i wzmocnić walkę z przeciwnikami wewnętrznymi. To pozwoliłoby wyeliminować główne zagrożenia dla relacji Wschód-Zachód i wzmocnić siły postępowe i reformatorskie w bloku wschodnim, gwarantujące pozostanie na linii zbliżenia między blokami, a tym samym zbliżenia obu państw niemieckich ${ }^{3}$. To przekonanie SPD bazowało przede wszystkim na poglądzie, że wewnątrz partii komunistycznych znajdowały się grupy, które były skłonne do reformy systemu i wejścia na drogę odgórnych reform wewnętrznych. To z nimi chciano współpracować, to im bardziej wierzono i dawano szansę. W budowaniu tej konstrukcji myślowej opierano się na informacjach uzyskanych w relacjach międzynarodowych partii i uprawianej przez nią „polityce zagranicznej”. Socjaldemokraci zawsze uczestniczyli w najważniejszych wydarzeniach międzynarodowych, zachowując się czasami, jakby SPD była nadal partią rządzącą i mającą realny wpływ na kształt wielkiej polityki.

W omawianym tutaj zagadnieniu pierwszoplanowe znaczenie miała wizyta Horsta Ehmkego w Moskwie w listopadzie 1988 roku$^{4}$. Chodziło wówczas o sprawdzenie charakteru, zasięgu i kierunku rozwoju pierestrojki, a także zbadanie jej wpływu na partie lewicowe w Europie. W Moskwie próbowano przekonać gościa z Bonn, że władze radzieckie nie chciały blokować reform i przemian w bloku, a wręcz stawiały na siły, które chciały zreformować własne państwo. Mowa była nawet o dopuszczeniu tak zwanego modelu węgierskiego, czyli ograniczonego pluralizmu. Podobno radzieccy eksperci byli zdania, że kwestia bezpieczeństwa ZSRR nie musiała być ściśle związana z kwestią systemu politycznego i była do pogodzenia z poparciem przez Moskwę wewnętrznych ruchów reformatorskich ${ }^{5}$. (O zauważalnej zmianie polityki ZSRR donoszono również $\mathrm{z}$ Waszyngtonu, $\mathrm{w}$ tym wypadku chodziło o raport przedstawiony przed komisją zagra-

2 Archiv der sozialen Demokratie (dalej: AdsD) SPD PV, Int. Abt. 910, Dr. Jutta Tiedke, Protokoll des Gespräches zwischen dem Partei- und Funktionsvorsitzenden der SPD, Dr. Hans-Jochen Vogel, und dem polnischen Ministerpräsidenten Mieczyslaw Rakowski am 20. Januar 1989, Bonn 23. Januar 1989.

${ }^{3}$ O ruchach odśrodkowych w bloku wschodnim zob. D. Preuße, Umbruch von unten. Die Selbstbefreiung Mittel- und Osteuropas und das Ende der Sowjetunion, Wiesbaden 2014.

4 AdsD, Vogel 821, Bericht über eine Informationsreise mit Horst Ehmke nach Moskau (14. bis 18. November 1988) von Heinz Timmermann. Nur für den persönlichen Gebrauch.

${ }^{5}$ Ibidem. Na gruncie polskim o stanowisku Gorbaczowa wobec przemian politycznych w bloku wschodnim pisze między innymi Antoni Dudek: „Kreml godził się wówczas na daleko idące zmiany w Polsce i innych krajach bloku, a priorytet stanowiło dlań utrzymanie w tych państwach spokoju wewnętrznego oraz współpracy politycznej i gospodarczej z ZSRR. Moskwa nie zamierzała oczywiście rezygnować z utrzymania Europy Środkowej w strefie swoich wpływów, ale - wobec rosnących trudności wewnętrznych uznała, że nie musi to być równoznaczne z podtrzymywaniem reżimów komunistycznych, które nie potrafią skutecznie kontrolować sytuacji społeczno-politycznej, a równocześnie przejść na nowe zasady wymiany gospodarczej. Zakładano, że kraje Europy Środkowej pozostaną członkami Układu Warszawskiego, a partie komunistyczne, ograniczając swój monopol władzy, nie doprowadzą do jej całkowitej utraty" - idem, Ankieta „Wolności i Solidarności”: Polski rok 1989, „Wolność i Solidarność. Studia z Dziejów Opozycji wobec Komunizmu i Dyktatury" 2014, nr 7, s. 23-25. 
niczną senatu USA ${ }^{6}$.) Jak wynika z zachowanych materiałów, większość polskich działaczy opozycyjnych zdawało sobie sprawę z istniejących zależności między powodzeniem reform w Polsce a powodzeniem pierestrojki w Związku Radzieckim ${ }^{7}$. Natomiast prof. Bronisław Geremek wiązał pierestrojkę, Gorbaczowa i reformę w PRL z możliwością interwencji radzieckiej w Polsce. Jego zdaniem, jak długo przy władzy pozostawał Gorbaczow, tak długo nie było zagrożenia interwencją ${ }^{8}$.

Drugim elementem, który zdecydował o pogłębionej obserwacji kształtującej się właśnie sceny politycznej w Polsce, była chęć jej poznania. Niemcy z RFN chcieli udzielić wsparcia siłom demokratycznym. W zależności od charakteru partii preferowano te ugrupowania, które były ideologicznie z nimi spokrewnione. Tak więc chadecy udzielali pomocy działaczom związanym z tym nurtem politycznym, a SPD wspierała przede wszystkim ugrupowania odwołujące się do ideałów socjaldemokratycznych ${ }^{9}$. Szczególne znaczenie poznawcze mają analizy przygotowane przez lewicowych polityków i związkowców z Niemieckiej Federacji Związków Zawodowych (dalej: DGB), którzy już od lata 1980 roku prowadzili rozmowy zarówno z przedstawicielami Solidarności, jak również z politykami i działaczami oficjalnych związków zawodowych w PRL ${ }^{10}$. Rozległe spektrum kontaktów pozwalało na szeroki wgląd w polską scenę polityczną w 1989 roku. Przy okazji próbowano określić kierunki jej rozwoju, stawiając pytania o to, jak wkrótce będzie wyglądać polska scena polityczna, jaka będzie demokracja i jaka będzie Solidarność. Te pytania stały się szczególnie aktualne i ważne od momentu rozpoczęcia obrad Okrągłego Stołu i widocznych podziałów w społeczeństwie polskim. Jak pisał Jerzy Holzer:

${ }^{6}$ Raport, którego autorem był Georg Kannan, mówił jednoznacznie, że ZSRR należało traktować jak każde inne mocarstwo i że jego polityka wynikała bardziej z położenia geograficznego, historii czy też tradycji, mniej z przekonań ideologicznych. W tej sytuacji kierunki polityki radzieckiej i jej interpretacja nie różniły się zasadniczo od polityki amerykańskiej i jej interpretacji. AdsD Bonn, SPD Bundestagfraktion, XI Wahlperiode (BTgF), 2/BTFK 56, Übersetzung, Erklärung vor dem Außenpolitischen Ausschuß des Senats der Vereinigten Staaten am 4. April 1989 von Georg F. Kennan.

7 Z tego grona wyłamywali się działacze zagranicznych struktur Solidarności, między innymi w Brukseli. O jednym z takich spotkań pisał kierownik wydziału zagranicznego DGB, Erwin Kristoffersen. Zdaniem działaczy brukselskich popularność Gorbaczowa w Europie była nieuzasadniona (nazwano ją "gorbomanią"), a przemiany, jakie zachodziły w ZSRR, były oceniane negatywnie. To stanowisko zostało określone jako wypowiedź „sfrustrowanych działaczy emigracyjnych”. AdsD DGB-Archiv 293, Erwin Kristoffersen, Internationale Abteilung, Vermerk für Ernst Breit, Betr.: Gespräch mit dem Solidarnosc-Büro in Brüssel, Düsseldorf, den 12 Dezember 1988.

8 Antoni Dudek twierdzi, że „nawet w przypadku »gwałtownego zaostrzenia się sytuacji«” wykluczano na Kremlu możliwość radzieckiej interwencji zbrojnej, która — jak głosiło opracowanie Wydziału Zagranicznego KC KPZR — „byłaby usprawiedliwiona tylko w jednym wypadku — bezpośredniego i oczywistego zbrojnego wmieszania się obcych sił w wewnętrzne sprawy socjalistycznego państwa”. - idem, op. cit., s. 23.

9 M. Świder, 1989 - rok przełomu i relacje polsko-niemieckie. Wsparcie SPD dla komitetu obywatelskiego „Solidarności”, [w:] 25 lat polskiej transformacji systemowej. Dokonania i wyzwania, t. 2, red. J. Kornaś, Ł. Daniel, Kraków 2014, s. 289-300. SPD miała również dobre kontakty z dostojnikami Kościoła katolickiego. Informacje uzyskane z tych kanałów nie będą brane pod uwagę w niniejszym opracowaniu.

10 O stosunku DGB do Solidarności i Polski na początku lat osiemdziesiątych XX wieku pisze M. Świder, Solidarność związkowa. Niemiecka Federacja Związków Zawodowych (DGB) wobec NSZZ „Solidarność, Kraków 2017; eadem, Solidarność związkowa. Zachodnioniemiecka pomoc humanitarna dla Polski (19821983), Kraków 2018. 
Mandat przywódców i doradców Solidarności do rozmów w imieniu społeczeństwa był kwestionowany przez rozmaite opozycyjne organizacje usamodzielnione wobec niej w latach osiemdziesiątych, a także przez niektórych działaczy Związku, niekiedy o dużej renomie, którzy w rozmowach widzieli w najlepszym razie pułapkę ze strony komunistów, w najgorszym — próbę zawarcia brudnego kompromisu i kontynuacji istniejącego systemu ${ }^{11}$.

W tym czasie w Bonn analizowano sytuację w Solidarności i możliwości jej ewaluacji organizacyjnej. Ponadto śledzono „trendy” polityczne wśród nowo powstałych organizacji o charakterze politycznym i społecznym, a także oceniano możliwości działalności politycznej Solidarności, co wiązało się z ewentualnym udzieleniem pomocy organizacyjnej i materialnej dla ugrupowań opozycyjnych ${ }^{12}$. Było to o tyle ważne, że chciano współpracować z ludźmi i organizacjami, które gwarantowały rozwój demokracji w Polsce. Przykładowo, w lutym 1989 roku podczas posiedzenia grupy roboczej „Nowe partie w Europie Wschodniej” w kręgach socjaldemokratycznych stwierdzono jednoznacznie i publicznie, że SPD będzie utrzymywać kontakty tylko z takimi ugrupowaniami politycznymi, które swoje opozycyjne stanowisko wykorzystują do wzmacniania procesu reform. Odcinano się od takich, które mogłyby destabilizować sytuację międzynarodową ${ }^{13}$. Jak zatem oceniano opozycję w Polsce?

Prezentowany tekst bazuje na wynikach badań prowadzonych w niemieckich archiwach, gdzie analizie poddano dokumenty wytworzone w kręgach politycznych i związkowych. Przeanalizowano głównie materiały związane z socjaldemokracją niemiecką i dokumenty powstałe pod koniec obrad Okrągłego Stołu oraz na początku czerwca 1989 roku, czyli zaraz po wyborach. Ich autorami byli zarówno działacze partyjni, jak i związkowcy z DGB, a także pracownicy Fundacji Friedricha Eberta z Bonn ${ }^{14}$. Również DGB utrzymywało kontakty polityczne zarówno ze stroną rządową w Polsce, jak i z przedstawicielami opozycji. Tutaj najważniejszą rolę odgrywał szef wydziału zagranicznego DGB, Erwin Kristoffersen. Natomiast Klaus Reiff, były attaché prasowy ambasady RFN w Warszawie, reprezentował Fundację Eberta, w której pracował po powrocie z placówki ${ }^{15}$.

\section{Przemiany w Polsce na początku 1989 roku}

Podstawowym problemem dla obserwatorów było określenie dalszego rozwoju sytuacji politycznej w Polsce. Chodziło nie tylko o rozwój szeroko pojętej Solidarności i Komitetu Obywatelskiego przy Przewodniczącym NSZZ „Solidarność” Lechu Wałęsie (później

11 J. Holzer, Solidarność i iluzja społeczeństwa bezkonfliktowego, „Wolność i Solidarność. Studia z Dziejów Opozycji wobec Komunizmu i Dyktatury” 2011, nr 2, s. 12, https://www.civitas.edu.pl/collegium/wp-content/uploads/2016/11/WiS_02_.pdf (dostęp: 5.10.2018).

12 Szerzej o wsparciu finansowo-organizacyjnym pisze M. Świder, 1989 - rok przełomu...

13 M. Świder, Stanowisko Socjaldemokratycznej Partii Niemiec wobec Polski w latach 1980-1989, Opole 2015, s. 449.

14 AdsD Ehmke 677, Hans Koschnick an Norbert Gansel, Bonn 10. Mai 1989.

15 Klaus Reiff posiadał na początku lat osiemdziesiątych rozbudowane kontakty z działaczami Solidarności, przede wszystkim z działaczami Regionu Mazowsze i dziennikarzami, zob. idem, Polen. Als deutscher Diplomat an der Weichsel, Bonn 1990. 
Komitet Obywatelski „Solidarność” - KO), lecz także o losy dotychczasowych ugrupowań politycznych. Pytaniem zasadniczym było, czy z szerokiego ruchu Solidarności wyłonią się partie polityczne, czy ruch ten zostanie zachowany jako jedna organizacja polityczna, a także jaką drogę obierze PZPR, dotychczasowy partner polityczny socjaldemokracji niemieckiej ${ }^{16}$. Problem rozeznania na budującej się scenie politycznej był kwestią pilną, wówczas nastąpiła bowiem już ilościowa eksplozja różnorodnych grup, stowarzyszeń i organizacji o różnych aspiracjach i poglądach politycznych. Były one trudne do zaklasyfikowania dla partnerów zagranicznych poszukujących odpowiednich partnerów do rozmów. W tym czasie w Solidarności zastanawiano się nad orientacją polityczną, biorąc pod uwagę model szwedzkiej socjaldemokracji czy też niemieckiej chadecji, która w tym czasie wykazywała wzmożoną aktywność w Polsce ${ }^{17}$. Dlatego ważna stała się prezencja polityków zachodnich w Warszawie i obserwacja zachodzących w Polsce przemian. Na wiosnę 1989 roku z wizytą do Polski przybyli Ehmke, Wischnewski i Kristoffersen z DGB, ponieważ politycy ci utrzymywali bliskie kontakty zarówno z rządem, jak i z opozycją w PRL, a ich analizy uwzględniały oba środowiska. (W tym czasie w Warszawie przebywali również politycy koalicji rządzącej CDU/CSU-FDP. To właściwie oni odgrywali zasadniczą rolę w kształtowaniu ówczesnych niemiecko-polskich stosunków dwustronnych. Na szczególne wskazanie zasługuje Horst Teltschik — jeden z najbliższych i najwierniejszych współpracowników kanclerza Kohla, w latach 1983-1990 wiceszef Urzędu Kanclerskiego, pełnomocnik kanclerza do rozmów z Polską ${ }^{18}$.)

Zachód nie wiedział, jak ma kształtować dialog z nowymi ugrupowaniami, nie prowokując przy tym napięć i zawirowań wewnętrznych i zewnętrznych ${ }^{19}$. Szczególnie socjaldemokraci mieli z tym problem, ponieważ z jednej strony nie chcieli narażać swoich dotychczasowych kontaktów z partiami starego typu, z drugiej zaś widzieli konieczność rozmów z opozycją. Problem wydawał się pilny, jak bowiem oceniał Mieczysław F. Rakowski w styczniowych rozmowach z politykami SPD, podjęto w kraju działania, które miały doprowadzić do zmian na scenie politycznej. Między innymi oczekiwano rejestracji około dziesięciu partii politycznych do końca 1989 roku. Istniały przy tym obawy, że większość z nich będzie partiami prawicowymi ${ }^{20}$. Socjaldemokraci byli zgodni co do tego, że należało szukać kontaktów, sygnalizować gotowość do rozmów, analizować pro-

16 AdsD Ehmke 677, SPD, der Parteivorstand, Internationaler Sekretär, an die Mitglieder der Koordinierungsgruppe für die laufenden internationalen Kontakte der SPD, Betr.: Zusammenfassung und Ergebnisse der Sitzung vom 14. Juni 1989.

17 AdsD Ehmke 678, Heinz Rapp an den Vorsitzenden der SPD, Herrn Dr. Hans-Jochen Vogel MdB, 24. April 1989, Betr.: Solidarność; na ten temat zob. D. Bingen, Die Polenpolitik der Bonner Republik von Adenauer bis Kohl, 1949-1991, Nomos 1998.

18 Horst Teltschik, Geschichte der CDU, Konrad-Adenauer-Stiftung, https://www.kas.de/web/geschichte-der-cdu/personen/biogramm-detail/-/content/horst-teltschik-v1 (dostęp: 3.02.2019).

19 AdsD Ehmke 677, Internationales Sekretariat, Veronika Isenberg, Vermerk, betr.: Sitzung des Arbeitsgruppe „Neue Parteien in Osteuropa“ am 17. Februar 1989, Bonn 22. Februar 1989.

20 AdsD Parteivorstand Int. Abt. 910, J. Tiedtke, Protokoll des Gespräches zwischen dem Partei- und Fraktionsvorsitzenden der SPD, Dr. Hans-Jochen Vogel, und dem polnischen Ministerpräsidenten Mieczyslaw Rakowski am 20. Januar 1989. 
gramy nowych ugrupowań, wymieniać się materiałami informacyjnymi i poznać ludzi stojących za tymi partiami i grupami ${ }^{21}$.

\section{Komitet Obywatelski}

Komitet Obywatelski był dla SPD głównym partnerem reprezentującym stronę opozycyjną. Z racji poglądów jego czołowych członków został uznany przez socjaldemokratów za właściwego partycypanta. To przede wszystkim ze strony $\mathrm{KO}$ wychodziły prośby o wsparcie techniczne i organizacyjne. W lutym 1989 roku podczas wizyty Ehmkego w Warszawie opozycja sugerowała SPD konieczność rewizji oficjalnej polityki partii wobec Polski (było to po spotkaniu Ehmkego z Alfredem Miodowiczem ${ }^{22}$ ). Chodziło o zastąpienie w oficjalnych kontaktach partyjnych PZPR Komitetem Obywatelskim. Za tą zmianą miała przemawiać orientacja polityczna opozycji, która według Janusza Onyszkiewicza była przede wszystkim socjaldemokratyczna (w rzeczywistości socjaldemokraci zdawali sobie sprawę z niejednorodności poglądów w KO). Rzecznik prasowy Komitetu twierdził nawet, że skrzydło chrześcijańsko-demokratyczne było „ledwie rozpoznawalne i stanowiło rzeczywistą mniejszość" ${ }^{23}$. Najprawdopodobniej decydujące znacznie dla poparcia KO miała analiza przygotowana przez Reiffa w kwietniu 1989 roku, w której przedstawiono Komitet jako zbiór liczących się sił politycznych posiadających bazę i strukturę umożliwiającą działalność i współpracę z innymi zagranicznymi siłami politycznymi. W kooperacji z Bronisławem Geremkiem i Kazimierzem Wójcickim opracowano wówczas katalog możliwych działań na rzecz Komitetu. Przede wszystkim SPD mogło pomóc w pracy parlamentarnej poprzez szkolenie asystentów posłów i senatorów pochodzących z kręgów solidarnościowych. Równie ważnym elementem mogło być przyznanie stypendiów naukowych dla doradców naukowych Komitetu, a także szkolenie w prowadzeniu walki wyborczej dla organizatorów wyborów - w tym wypadku chodziło o przyszłe wybory samorządowe. Zgodnie z obserwacjami, jakich RFN dokonał w Warszawie, wykluczał możliwość przekształcenia się Komitetu w jedną partię polityczną, ponieważ skupionych było w nim zbyt wiele różnych kierunków, często z sobą konkurujących ${ }^{24}$.

Do tematu orientacji ideologicznej KO powracano jeszcze wielokrotnie. Przykładowo prof. Bronisław Geremek oceniał w sierpniu 1989 roku, że w klubie parlamentarnym

21 AdsD Ehmke 677, Internationales Sekretariat, Veronika Isenberg, Vermerk, betr.: Sitzung des Arbeitsgruppe „Neue Parteien in Osteuropa” am 17. Februar 1989, Bonn 22. Februar 1989.

22 W trakcie czterodniowej wizyty Ehmke spotkał się z najważniejszymi osobami w państwie: generałem Jaruzelskim, prymasem Glempem, premierem Rakowskim, Miodowiczem, Tadeuszem Olechowskim, Józefem Czyrkiem i działaczami opozycji, biorącymi udział w obradach Okrągłego Stołu. AdsD Ehmke 800, H. Ehmke, Besuchsprogramm Warschau 7.-10. Februar 1989, Februar 1989.

23 AdsD Koschnick 371, Prof. Dr. Gottfried Erb, Herrn Hans Jochen Vogel Vorsitzender der SPD, 24. April 1989.

24 AdsD Ehmke 678, Klaus Reiff, Zur politischen Lage in Polen nach den Wahlen zum Parlament (Sejm) und zum Senat am 4. und 18 Juni 1989. 
KO więcej niż połowa posłów reprezentowała poglądy socjaldemokratyczne, jednak baza Komitetu była w zasadzie chadecka ${ }^{25}$. Mogło to oznaczać, że proces kształtowania orientacji politycznej największych obozów i grup opozycyjnych w Polsce nie został jeszcze zakończony.

Z punktu widzenia kompleksowości informacji uzyskanych z Polski na uwagę zasługuje przywołana analiza sytuacji w Polsce, przygotowana przez szefa Wydziału Zagranicznego DGB w kwietniu 1989 roku. Powstała na bazie rozmów prowadzonych w Warszawie, zarówno z przedstawicielami rządu, związków zawodowych, jak i Solidarności. Podstawowym wnioskiem, jaki został wyciągnięty przez Kristoffersena, było stwierdzenie, że po pierwsze Solidarność wprawdzie uzyskała więcej, niż oczekiwała, ale straciła przy tym „polityczną niewinność” 26 , a po drugie, że wewnątrz obozu rządzącego doszło do głębokich podziałów. Zauważył również, że istniała pilna konieczność zmian politycznych, bez których państwo nie mogło funkcjonować ${ }^{27}$. W kręgach rządowych Kristoffersen wyodrębnił dwie grupy: ortodoksyjną i reformistyczną. Pierwsza z nich dopuszczała zmiany i reformy zasadniczo tylko w dziedzinie gospodarczej, jednak bez określenia ich zakresu. Reformy obejmujące pluralizm związkowy i demokratyzację polityki spotykały się z zaciętym oporem tej części rządzących. Również grupa reformistyczna nie była przekonana do zakresu proponowanych przemian. Wydawało się, że partia (jako całość) pogodziła się z koniecznością dopuszczenia do głosu środowisk opozycyjnych. Nie chciała jednak dopuścić do odsunięcia jej od władzy, podnosząc, że może to prowadzić do chaosu i konfrontacji, dlatego zaproponowano wyjście pośrednie, jakim był konsensus w procentowym podziale głosów w przyszłym sejmie ${ }^{28}$.

Kristoffersen, analizując stosunek rządzących do Solidarności, odnosił wrażenie, że w kręgach partyjnych istniały głębokie różnice zdań na temat formy przywrócenia Solidarności do legalności. Negatywnie do tej kwestii odnosiły się związki zawodowe skupione w OPZZ, które zgadzały się jedynie na stopniowe wprowadzanie pluralizmu związkowego, poprzedzonego szerokimi konsultacjami. Mechanizmem obronnym przed zmianami była ofensywa polegająca na głoszeniu haseł populistycznych, konkurujących z żądaniami Solidarności, a także prowokowanie i organizowanie akcji mających zakłócić obrady Okrągłego Stołu. Kristoffersen uzasadniał tę akcję (między innymi organizację strajków) obawami przed utratą członków przez OPZZ ${ }^{29}$.

Ciągle otwartym pytaniem była kwestia roli, jaką Solidarność miała odgrywać po legalizacji. Umiarkowani działacze opozycyjni byli zdania, że po osiągnieciu pluralizmu partyjnego Solidarność powinna być „jedynie” związkiem zawodowym. Potwierdze-

25 AdsD Ehmke 465, Aufzeichnung über meine Gespräche mit Professor Bronislaw Geremek in Warschau 30./31. August 1989. Heinrich August Winkler. Do spotkania doszło przy okazji wizyty Johannesa Raua w Warszawie.

26 AdsD Koschnik 377, Erwin Kristoffersen, DGB-Bundesvorstand, Internationale Abteilung, Erfolg am Runden Tisch. Eindrucke von meinem Besuch in Warschau in der Zeit vom 1. bis 4. April 1989.

27 Ibidem, załącznik: Erwin Kristoffersen, Vereinbarter Wandel am Runden Tisch? Eindrucke während eines Warschau-Aufenthalts vom 6. bis 12. Februar 1989.

${ }^{28}$ Ibidem.

29 Ibidem. 
niem tej tezy miało być zapewnienie Wałęsy, że nie będzie kandydował w wyborach do sejmu. Pomysł ograniczenia politycznej roli Solidarności nie był w pełni akceptowany, obawiano się bowiem utraty jej atrakcyjności. Inni oczekiwali od Solidarności zajęcia jednoznacznego stanowiska prorobotniczego oraz mocnej, zdecydowanej i konsekwentnej reprezentacji interesów klasy robotniczej. Rozwiązaniem tego dylematu miało być większe zaangażowanie międzynarodowe Solidarności i możliwość uczenia się od innych, starszych związków zawodowych ${ }^{30}$. W praktyce oznaczało to, że Solidarność i jej działacze zwracali się o pomoc organizacyjną i materialną do bardziej doświadczonych związkowców, co już wcześniej było sygnalizowane.

\section{Sytuacja po wyborach czerwcowych}

Jednym z bardziej kompleksowych opracowań sytuacji w Polsce był raport pracownika Fundacji Eberta i specjalisty od spraw polskich, Klausa Reiffa ${ }^{31}$. Powstał on w „gorącej atmosferze" powyborczej, gdyż wizyta Reiffa miała miejsce w dniach 6-10 czerwca 1989 roku, a jej zasadniczym celem było zorientowanie się w ogólnej sytuacji w Polsce, a także rozpoznanie możliwości współpracy Fundacji Eberta z opozycją. W analizie Reiff ukazał powstały po wyborach układ sił politycznych, zakończony konkluzją, że Polska znajdowała się w wyjątkowo krytycznej sytuacji politycznej i katastrofalnej sytuacji gospodarczej. Ta na wskroś pesymistyczna opinia poparta była szeroką analizą, wynikającą z rozmów z działaczami partyjnymi ${ }^{32}$ i opozycyjnymi ${ }^{33}$. Przede wszystkim Reiff wskazał na skomplikowaną sytuację wynikającą z rozdrobnienia sceny politycznej. Przy mnogości grup opozycyjnych i klubów politycznych uznał Komitet Obywatelski za najbardziej poważną i wpływową grupę, skupiającą silne ugrupowania mogące skutecznie konkurować z PZPR. Jednym z najważniejszych przywódców tego ugrupowania był prof. Geremek, który jak podkreślono w sprawozdaniu, otwarcie przyznawał się do swoich socjaldemokratycznych przekonań. Innym wpływowym działaczem (w sumie było ich stu dziewiętnastu) był przewodniczący Polskiej Partii Socjalistycznej, Jan Józef Lipski, który był znany w kręgach socjaldemokratycznych. SPD udzielała pomocy materialnej PPS w jej działalności organizacyjnej, finansując na przykład kongresy partii na emigracji. Rów-

\section{Ibidem.}

31 AdsD Koschnick 352, Bericht. Gespräche in Warschau nach den Wahlen zum Parlament und zum Senat vom 6. bis 10. Juni 1989, s. 1-2.

32 Ze strony rządu rozmówcami Reiffa byli: prof. J. Reykowski - członek Biura Politycznego (BP) Komitetu Centralnego PZPR (KC PZPR), S. Ciosek — zastępca członka BP i Sekretarz KC PZPR, E. Michałowska - pracownik Wydziału Zagranicznego KC PZPR, J. Urban - były rzecznik prasowy rządu PRL, przewodniczący Komitetu ds. Radia i Telewizji, A. Brzeziński — zastępca dyrektora wydziału IV w MSZ (niemieckojęzyczna zagranica).

33 Partnerami rozmów Reiffa ze strony opozycji byli: prof. B. Geremek — przewodniczący komisji ds. reform politycznych przy KO, J. Onyszkiewicz - rzecznik prasowy NSZZ „Solidarność, K. Wójcicki — zastępca sekretarza KO, A. Micewski - dziennikarz katolicki, doradca prymasa Glempa. 
nież Willy Brandt jako przewodniczący Międzynarodówki Socjalistycznej interesował się polskimi socjalistami ${ }^{34}$.

Geremek był partnerem rozmów na temat przyszłości Komitetu. Według opinii profesora Komitet w kształcie, w jakim przystąpił do wyborów czerwcowych, miał istnieć jeszcze dwa lata. Po wyborach samorządowych, które miały zakończyć proces demokratyzacji kraju, powinny wykształcić się z niego partie polityczne, które po czterech latach miały wziąć udział w całkowicie wolnych wyborach. Geremek i wszyscy rozmówcy z opozycji podkreślali, że Komitet jest zwolennikiem ewolucyjnych zmian i zachowania ustaleń Okrągłego Stołu. Dlatego następnym etapem demokratyzacji życia politycznego w Polsce miały być wybory do struktur samorządowych. Około dziesięciu tysięcy kandydatów musiało być przygotowanych do walki wyborczej, w której stare struktury polityczne miały ponieść druzgocącą klęskę ${ }^{35}$. Innym istotnym elementem demokratyzacji życia politycznego w Polsce miała być walka z nomenklaturą, o której Geremek mówił, że była problemem kluczowym, jak bowiem obliczano, było przez nią obsadzonych około ośmiuset tysięcy miejsc w przemyśle. Do tego dochodziły stanowiska w administracji, wojsku i dyplomacji. Spodziewano się trudnej walki z PZPR o jej usunięcie, ponieważ nawet przy Okrągłym Stole partia nie godziła się na jakiekolwiek ustępstwa czy chociażby rozmowy na ten temat.

Obserwując rozwój sytuacji w Warszawie, a także prowadząc rozmowy w kręgach opozycyjnych, Reiff naszkicował główne zadania i kierunki rozwoju Komitetu Obywatelskiego. Przede wszystkim Komitet miał zachować zasadę ewolucyjności i szanować wszystkie formy i prawa własności. „Solidarność” „rozumiała się” jako związek zawodowy, nie zaś jako partia, i temu miała być podporządkowana działalność na rzecz zachowania sprawiedliwości społecznej. Dla obserwatora zagranicznego ważnym elementem przemian i dojścia do głosu nowych sił politycznych było pytanie dotyczące respektowania i wypełniania wszelkich zobowiązań i umów międzynarodowych. Opozycjoniści uspokajali, potwierdzając gotowość wypełnienia wszelkich zobowiązań międzynarodowych Polski.

${ }^{34}$ Wprawdzie doceniano PPS, ale z dezaprobatą przyglądano się w Bonn rozbiciu tej partii z powodu radykalnych tendencji niektórych działaczy, bliskości z Kościołem katolickim, różnych wyobrażeń dotyczących statutu, struktury, strategii i taktyki partii, a także istniejącego konfliktu generacyjnego. Chodziło o konflikt między Prezydium Rady Naczelnej (Lipski i Kunicki-Goldfinger), które powoływało się na międzywojenne tradycje partii, a Centralnym Komitetem Wykonawczym, który skupiał głównie ludzi młodych. Starzy działacze PPS opowiadali się za umiarkowanym programem, młodzi natomiast za radykalnym). Zapowiedź „młodych” działaczy PPS dotycząca eskalacji programu i działań budziła niepokój w SPD, która oceniła PPS jako partię radykalną, gotową zastosować skrajne metody walki z PZPR i obowiązującym w PRL systemem prawnym. Do rozłamu doszło pod koniec 1988 roku. W 1989 roku oba nurty uważały się za legalnych spadkobierców międzywojennych tradycji PPS. Dla SPD ważny był stosunek socjalistów polskich od idei Okrągłego Stołu. Próby uzgodnienia z Wałęsą deklaracji PPS i jej stosunku do Solidarności i Okrągłego Stołu podjęte przez Lipskiego zostały zbojkotowane przez odłam młodych jako zbyt ugodowe. Poparcie Rady Najwyższej dla Okrągłego Stołu dodatkowo utrwaliło rozbicie wewnętrzne i doprowadziło pod koniec 1989 roku do zmarginalizowania PPS.

35 AdsD Koschnick 352, Zur politischen Lage in Polen nach den Wahlen zum Parlament (Sejm) und zum Senat am 4. Und 18 Juni 1989, s. 5. 
Wszystkie aspekty poruszane przez Reiffa w rozmowach z przedstawicielami opozycji skupionymi w Komitecie napawały ograniczonym optymizmem. Mówiąc o sukcesie i poparciu społecznym dla opozycji, Reiff po rozmowie z Geremkiem zwrócił uwagę na dwa bardzo niekorzystne aspekty. Po pierwsze, z łona „Solidarności” wyłoniła się grupa, która całkowicie odrzucała porozumienie z PZPR, dążąc do siłowego obalenia komunizmu. Była to „Solidarność Walcząca”. Pojawiły się również równoległe struktury w „Solidarności", które stały w opozycji do Wałęsy. Po drugie, niekorzystnym zjawiskiem, które mogło rozrosnąć się w przyszłości do poważnego problemu, było zachowanie wyborcze ponad czterech milionów wyborców. Absencja wyborcza czy też oddanie nieważnego głosu mogły świadczyć o braku zgody na kompromis wypracowany przy Okrągłym Stole.

Podczas wizyty w Warszawie Reiff miał również możliwość rozmowy z przedstawicielami PZPR. Pierwszy najważniejszy wniosek, jaki przytoczył Reiff, mówił o głębokim szoku w szeregach partii, spowodowanym wynikami wyborów. Sama walka wyborcza ze strony PZPR była prowadzona w sposób niemrawy, a wielu kandydatów wystawionych na listach wyborczych ukrywało swoją przynależność do partii, chcąc w ten sposób poprawić swoje szanse na wybór. Sytuacja ta wynikała z tego, jak pisał Reiff, że już pod koniec lat siedemdziesiątych XX wieku partia była zbiorowiskiem ludzi zainteresowanych głównie przywilejami i korzyściami, traktujących Polskę jak sklep samoobsługowy. Gniew i niezadowolenie członków partii były kanalizowane w krytyce zagranicznych partii politycznych, na przykład SPD ${ }^{36}$. Jednocześnie wykorzystywano każdy oficjalny i nieoficjalny kontakt z SPD dla wzmocnienia swojej legitymizacji politycznej w kraju. Wybory czerwcowe zredukowały PZPR do jej prawdziwej wielkości. Po czterdziestu pięciu latach partia musiała oddać władzę, z czego zdawała sobie sprawę grupa reformatorów z PZPR, a także poddać się zmianom i nowemu określeniu jej zadań, a przede wszystkim musiała rozstać się z ortodoksyjnymi działaczami. Reformatorzy byli jednomyślni co do konieczności przyjęcia nowego kierunku rozwoju - najpewniej socjaldemokratycznego. Wśród członków PZPR nie brakowało głosów nawołujących do współpracy, głównie w kwestiach gospodarczych. Szczególnie w obliczu katastrofalnej sytuacji gospodarczej każda pomoc byłaby dobrze widziana (to było stanowisko Stanisława Cioska). Miano nadzieję włączyć działaczy opozycyjnych w rozwiązywanie problemów, dlatego też bardzo pozytywnie przyjęto organizowanie przez Wałęsę pomocy gospodarczej za granicą. Minister do spraw współpracy ze związkami zawodowymi Józef Oleksy miał nawet powiedzieć do Reiffa, że Wałęsa prowadzi misję patriotyczną ${ }^{37}$.

Reasumując spotkania i rozmowy prowadzone w Warszawie, Reiff był zdania, że przemiany społeczno-polityczne, jakie zachodziły nad Wisłą, były nie tylko bardzo złożone i niejednoznaczne, lecz także miały znaczny wpływ na relacje międzynarodowe. W dobrze pojętym interesie ogólnoeuropejskim leżało poparcie dla przemian w Polsce. Mając na uwadze specjalne relacje niemiecko-polskie, RFN powinno w tym procesie

36 SPD posądzana była o nadmierne zbliżenie i pomoc opozycji. Reiff był zdania, że wszelka sympatia dla socjaldemokratów, jaka istniała w szeregach PZPR, a wynikała z polityki i działań Willy Brandta, została przysłonięta oskarżeniami o preferencję opozycji w kontaktach polsko-niemieckich. Więcej na temat relacji SPD-PRL zob. M. Świder, Stanowisko Socjaldemokratycznej Partii...

37 Ibidem, s. 462. 
odegrać decydującą rolę. Bez materialnej pomocy z zachodu proces reform w Polsce mógł być zagrożony. Niepokoje i protesty głodowe były pochodną wyjątkowo trudnej sytuacji gospodarczej w Polsce. Wspólny program gospodarczy EWG, USA i Kanady mógł pomóc $\mathrm{w}$ rozwiązaniu problemów. W Warszawie wszystkie siły polityczne, zarówno partia, jak i opozycja, były zdania, że RFN w tych działaniach powinno przejąć pierwszoplanową rolę. Należało również udzielić wsparcia organizacyjnego nowej sile politycznej wyłonionej w wyborach, która chciała wziąć odpowiedzialność za Polskę. Co ciekawe, również PZPR była potencjalnie zainteresowana współpracą w opracowaniu praktycznych form nowej socjaldemokratycznej działalności partyjnej.

Oceniając sytuację po wyborach czerwcowych 1989 roku, Reiff przekazał Zarządowi SPD, a także Zarządowi Fundacji Eberta w Bonn skomplikowany obraz stosunków wewnętrznych w Polsce. Oprócz bardzo pozytywnych zjawisk, jakie miały miejsce na budzącej się scenie politycznej, nie brakowało zagrożeń i niebezpieczeństw dla jej istnienia, jednak wszyscy uczestnicy życia politycznego świadomi byli wagi zachodzących przemian. Strona niemiecka była zainteresowana tymi przemianami oraz aktywnym uczestnictwem w nich, chociaż nie znała odpowiedzi na kilka zasadniczych pytań. W Bonn nie wiedziano, czy Solidarność pozostanie jedną organizacją, czy też rozpadnie się na wiele różnych ugrupowań, czemu sprzyjały narastające wśród posłów i senatorów Solidarności tendencje do uniezależnienia się od $\mathrm{KO}^{38}$. To mogło skomplikować sytuację na polskiej scenie politycznej i pozbawić skrzydło socjaldemokratyczne realnych wpływów politycznych, a także uaktywnić nastroje konserwatywne. Cały czas w SPD miano nadzieję, że w Europie Wschodniej dojdzie do odrodzenia się myśli socjaldemokratycznej. Willy Brandt, przewodniczący Międzynarodówki i honorowy przewodniczący SPD, w marcu 1989 roku mówił o dwóch interesujących procesach zachodzących w Polsce (i na Węgrzech): „socjaldemokratyzacji” istniejących grup politycznych i „ponownej socjaldemokratyzacji” w przypadku odradzających się grup ${ }^{39}$. Mimo że Brandt publicznie zapewniał o niemieszaniu się Międzynarodówki w tego typu procesy na wschodzie Europy, w praktyce nie tylko komentowała sytuację, lecz także aktywnie wspierała ugrupowania polityczne o programie zbliżonym do swojego. Przykładowo w czerwcu 1989 roku podczas XVIII Kongresu Międzynarodówki Socjalistycznej w Sztokholmie zwracano uwagę na przemiany w bloku wschodnim, głównie w Polsce i na Węgrzech. Podjęto wówczas problem wsparcia dla demokratyzacji socjalizmu ${ }^{40}$. Jak wynika z dokumentów, działania takie, prowadzone za pośrednictwem Międzynarodówki Socjalistycznej, podejmowały również siostrzane partie: SPÖ z Austrii i SAP ze Szwecji ${ }^{41}$.

Dla socjaldemokratów problemem były siły odśrodkowe, które powstały w Solidarności (Klaus Reiff zwrócił uwagę w przytaczanej analizie na wspomnianą już wcześniej „Soli-

38 AdsD Ehmke 677, An die Mitglieder der Koordinierungsgruppe für die laufenden internationalen Kontakte der SPD, Betr.: Zusammenfassung und Ergebnisse der Sitzung vom 14. Juni 1989.

39 AdsD Bundestagsfraktion 55, Mappe A, Protokoll, 14. März 1989.

40 Archiwum Akt Nowych, KC PZPR LXXVII 64, Sprawozdanie z XVIII Kongresu Międzynarodówki Socjalistycznej, Sztokholm, 20-22 czerwca 1989 roku.

${ }^{41}$ SPÖ - Socjaldemokratyczna Partia Austrii - Sozialdemokratische Partei Österreichs; SAP — Szwedzka Socjaldemokratyczna Partia Robotnicza - Sveriges Socialdemokratiska Arbetareparti. 
darność Walczącą", która odrzucała kompromis okrągłostołowy i domagała się rewolucyjnych zmian, przy okazji zwalczając tak zwane umiarkowane skrzydło Solidarności, a także Wałęsę i jego doradców) ${ }^{42}$. Temat ten stał się przedmiotem rozmów z przedstawicielami obozu rządowego. Jak wynika $\mathrm{z}$ analizy przygotowanej przez sekretarza międzynarodowego zarządu SPD, w połowie sierpnia 1989 roku w Warszawie dyskutowano o rozwoju opozycji, stawiając przy tym pod znakiem zapytania ustalenia Okrągłego Stołu. Natomiast nowy ambasador PRL w Kolonii, Stanisław Brzeziński, twierdził (uogólniając), że opozycja chciała całkowitej władzy i odejścia od przemian ewolucyjnych i pójścia w kierunku zmian radykalnych. Wizualizacją tych dążeń miały być plany obsadzenia funkcji premie$\mathrm{ra}^{43}$. Można również przyjąć, że temat rozgrywek wewnętrznych w obozie szeroko pojmowanej Solidarności o zakres przekazanej władzy był przedmiotem dyskusji w kręgach międzynarodowych. Mogły o tym świadczyć informacje pozyskane przez Hansa-Eberharda Dingelsa, sekretarza do spraw zagranicznych SPD, od pracownika ambasady węgierskiej w RFN na spotkaniu, które odbyło się zaledwie dzień wcześniej, to jest 15 sierpnia 1989 roku. Według „osoby kontaktowej” w Warszawie miała miejsce „teatralna burza”, wywołana niezręcznymi posunięciami taktycznymi czy też osobistymi ambicjami, i to po obu stronach. W rzeczywistości sytuacja była znacznie spokojniejsza, ponieważ główni aktorzy polskiej sceny politycznej ustalili już podczas obrad Okrągłego Stołu, że komunistycznemu prezydentowi przeciwstawiony będzie premier pochodzący z szeregów Solidarności ${ }^{44}$.

\section{Różnorodność polskiej sceny politycznej}

Kolejnym problemem dla zachodnioniemieckich polityków były ilościowe i jakościowe zmiany na polskiej scenie politycznej. Powstała olbrzymia liczba nowych ugrupowań, co znacznie utrudniało zagranicznym obserwatorom orientację w sytuacji w Polsce. Dlatego w ocenie polskiej sceny politycznej wspomagano się wiedzą naukowców. W tym wypadku był to Georg Waldemar Strobel, filolog, historyk i politolog, znawca historii Polski i badacz stosunków niemiecko-polskich z Bundesinstitut für ostwissenschaftliche und internationale Studien (BIOst $)^{45}$, już wcześniej publikujący na temat Solidarności ${ }^{46}$.

42 AdsD Ehmke 678, Klaus Reiff, Zur politischen Lage in Polen nach den Wahlen zum Parlament (Sejm) und zum Senat am 4. und 18 Juni 1989.

43 Była to rozmowa prowadzona przez H.E. Dingelsa ze Zbigniewem Brzezińskim, który mówił między innymi, że postawa Solidarności była „trudna do przekazania” innym przywódcom państw Układu Warszawskiego. Zwrócił również uwagę, że brak stabilności w Polsce mógł mieć negatywny wpływ na przebieg pierestrojki w Związku Radzieckim. AdsD Koschnick 337, Internationaler Sekretär Hans-Eberhard Dingels, Vermerk für H.-J. Vogel, J. Rau, W. Brandt, A. Fuchs, H. Koschnik, H. Ehmke, K. Voigt, Betr.: Die gegenwärtigen politischen Entwicklung in Polen, 16.08.1989, Persönlich/Vertraulich.

44 Ibidem.

45 O tym badaczu urodzonym w 1923 roku w Łodzi pisze m.in. A. Pol, Georg Waldemar Strobel (19232010), jego recepcja Wincentego Pola. Przyczynek selektywny do stosunków niemiecko-polskich drugiej połowy XX wieku, „Echa Przeszłości” 11, 2010, s. 341-355.

${ }^{46}$ G.W. Strobel, NSZZ „Solidarność”: Beitrag zur politischen Wirkungsanalyse einer sozialen Sammlungsbewegung, „Berichte des Bundesinstituts für Ostwissenschaftliche und Internationale Studien” 1983, z. 9. 
To on przygotował informacje o nowych ugrupowaniach, ich nazwach i programach ${ }^{47}$. Wśród ponad stu czterdziestu różnych grup opozycyjnych, z których przynajmniej szesnaście uważało się za partie polityczne, były organizacje społeczno-kulturalne wyznaniowe i bezwyznaniowe, organizacje ogólnopolityczne, organizacje praw człowieka, młodzieżowe i studenckie, organizacje związane z byłymi ziemiami polskimi, organizacje mniejszościowe, kombatanckie, społeczno-gospodarcze i kluby dyskusyjne ${ }^{48}$. Większość z nich wywodziła się z działalności konspiracyjnej, dlatego trudno było jednoznacznie określić ich program. W związku z tym posługiwano się nazwą, która go często zastępowała. Przy analizie programów nowo powstałych ugrupowań konieczna była znajomość polskiej historii, tradycji i symboliki, ponieważ przy ich tworzeniu i nazywaniu posługiwano się asocjacjami historycznymi. Odnosiło się to szczególnie do ugrupowań opozycyjnych, które traktowały symbole i tradycje, a także symboliczne określenia i terminy jako integralną część programu. Georg W. Strobel w przygotowanym dla SPD zestawieniu podał między innymi następujące przykłady łączące nazwy i nazwiska z jednoznacznymi treściami politycznymi: „Niepodległość” — niepodległość państwowa i polityczna niezależność, „Sybirak” - patriota antyrosyjski, szczególnie wyrazisty z racji przeżytych cierpień, PPS - antyrosyjski, narodowo zorientowany socjalizm, „Grunwald” - ugrupowanie antyniemieckie, „Szaniec” - prawicowy patriotyzm i nacjonalizm, „Stańczyk” - polski konserwatyzm, Roman Dmowski - narodowy, krytyczny wobec Niemiec i prorosyjski program, Józef Piłsudski - antyrosyjski i antyniemiecki patriotyczny program itd. Jednocześnie Strobel zrewidował klasyfikację PPS, którą uznał za partię katolicką o orientacji lewicowej, a nie socjalistyczną. Miała o tym świadczyć Deklaracja PPS, której bliżej było do nauki społecznej Kościoła, a szczególnie Jana Pawła II, niż do teorii marksizmu, a także brak w programie ważnych elementów socjalistycznych, nawiązujących do tradycji PPS w II Rzeczypospolitej ${ }^{49}$.

Duża liczba różnorodnych organizacji powodowała, że ich członkowie należeli do kilku równocześnie. Dochodziło również do wzajemnego przenikania się programów i inicjatyw, w efekcie czego powstała trudna do sklasyfikowania i rozpoznania sieć organizacji politycznych. Członkostwo w nich było nierzadko symbolem określonego statusu, nie zaś konkretnych oczekiwań programowych ${ }^{50}$. Cechą charakterystyczną podkreślaną przez G. Strobla było znaczne zaangażowanie się w ich działalność intelektualistów. Robotnicy praktycznie nie uczestniczyli w takich działaniach, chyba że mały one cele związkowe. Niektórzy działacze opozycyjni stawiali sobie pytanie o efektywność takiej struktury życia politycznego w Polsce. Podczas jednej z dyskusji w Warszawskim Klubie Politycznym „88”51, jak pisał G. Strobel, nazwano opozycję w Polsce grupą interesu. Opozycja nie miała pozytywnego politycznego programu, który byłby przemyślanym

47 AdsD Koschnick 379, Georg W. Strobel, Die sozialistische Opposition in Polen. Probleme - Organisationen.

48 Ibidem.

49 Ibidem.

50 Ibidem.

51 Klub Polityczny „88” powstał 20 października 1988 roku w Warszawie. W skład komitetu założycielskiego wchodzili między innymi: Krzysztof Czabański, Wojciech Giełżyński, Wojciech Lamentowicz, Józef 
programem funkcjonującym na zasadzie alternatywy istniejącego systemu politycznego. W związku z tym niekiedy pojawiały się pasywność i letarg ${ }^{52}$.

Brak pozytywnego programu, wewnętrzne napięcia i sprzeczne interesy, a także bierność znacznej części społeczeństwa, o których pisał G. Strobel, zachodnioniemieccy politycy zauważyli już wcześniej. Przykładowo w kwietniu 1989 roku, czyli w dniach kończących obrady Okrągłego Stołu, w sprawozdaniu z podróży do Polski Kristoffersen pisał o powszechnym letargu ogarniającym Polaków. Większość społeczeństwa nie brała emocjonalnego udziału w Okrągłym Stole, przyjmując wobec niego postawę wyczekującą i sceptyczną. Do Okrągłego Stołu najgorzej ustosunkowani byli ludzie młodzi, którzy niekiedy postrzegali go jako zdradę. Wielu z nich było zdania, że komuniści nie rozmawiali otwarcie i uczciwie, a inni domagali się rewolucyjnych zmian. Nie wiadomo było, jak ta grupa ustosunkuje się do ustaleń Okrągłego Stołu ${ }^{53}$.

\section{Quo vadis Polonia?}

Konstytucję zmieniono 29 grudnia 1989 roku, usuwając fragment mówiący o przewodniej roli PZPR, zmieniając nazwę państwa na Rzeczpospolita Polska i przywracając koronę orłowi w godle. Ta wizualizacja zamian, jakie zarysowały się w 1980 roku i doprowadziły do przemian politycznych w 1989 roku, nie oznaczała bynajmniej jedności politycznej ani wśród grup wyrosłych z opozycji, ani wśród grup wywodzących się z ugrupowań rządowych. W okresie kadencji Sejmu Kontraktowego w Obywatelskim Klubie Parlamentarnym skupiającym solidarnościową opozycję zjednoczoną dotąd w obliczu wspólnego wroga (PZPR) zarysowały się podziały na tle różnic w podejściu do radykalizmu, sposobu i tempa przemian ustrojowych oraz wizji docelowego systemu społecznego. Wobec zbliżających się wyborów samorządowych wiosną 1990 roku Wałęsa wezwał do dzielenia się środowisk solidarnościowych na lewicę i prawicę, określając tę sytuację jako „wojnę na górze” ${ }^{4}$. Obserwatorzy zewnętrzni, w tym z SPD, mieli poważną trudność w określeniu dalszych losów znanych im działaczy Solidarności. Nie wiedzieli, czy Solidarność zostanie związkiem zawodowym, czy też może będzie mutować w kierunku partii politycznej, a jeżeli tak, to o jakim zabarwieniu. Jak należało ocenić i zakwalifikować poszczególne nowo powstałe ugrupowania polityczne? Zaistniałą sytuację obserwatorzy skomentowali jako brak zdecydowania i dojrzałości politycznej. Problemy ze zdefiniowaniem własnej roli, jaką zauważano w przypadku Solidarności, szczególnie po jej kongresie w kwietniu 1990 roku, zachodni obserwatorzy związani ze związkami

Orzeł, Marek Rapacki, Henryk Szlajfer. Udział w działalności klubu brali także Marcin Król (Respublika) i Jan Józef Lipski.

52 AdsD Koschnick 379, Georg W. Strobel...

53 AdsD, Koschnik 377, Erwin Kristoffersen, DGB-Bundesvorstand, Internationale Abteilung, Erfolg am Rundem Tisch. Eindrücke von meinem Besuch in Warschau in der Zeit vom 1. bis 4. April 1989.

54 I. Słodkowska, Partie i ugrupowania polityczne polskiej transformacji, [w:] Zbiorowi aktorzy polskiej polityki, red. J. Wasilewski, Warszawa 1997, s. 31, http://www.academia.edu/16435949/Czynniki_dynamizuj\%C4\%85ce_zmiany_polskich_elit_politycznych_po_roku_1989 (dostęp: 5.10.2018). 
zawodowymi skomentowali jako brak pomysłu na to, co z sobą zrobić. W efekcie każdy robił to, co uważał za stosowne. Dodatkowym elementem wzmacniającym brak orientacji była nieznajomość rzemiosła pracy związkowej i funkcji prawdziwego związku zawodowego jako przedstawiciela klasy robotniczej ${ }^{55}$. Niestety, wszystkie obawy i znaki zapytania odnoszące się do dalszych losów Solidarności, stały się aktualne wiosną 1990 roku.

Pod koniec sierpnia 1990 roku Erwin Kristoffersen jeszcze raz dokonał oceny polskiego Okrągłego Stołu ${ }^{56}$. Ustalenia między rządem a Solidarnością, dotyczące rozwoju Polski i jej drogi do demokracji, były ostatnim aktem na scenie politycznej, który odegrano według planu. Późniejsze wypadki nie tylko przewyższyły oczekiwania obu stron, lecz także zmieniły charakter $z$ ewolucyjnego na rewolucyjny ${ }^{57}$. Zmieniła się również ocena samego Okrągłego Stołu. Na wiosnę 1989 roku kompromis przy nim osiągnięty wydawał się przełomowym wydarzeniem w bloku wschodnim. Półtora roku później niepopularne stało się powoływanie na niego. Jak podkreślał Kristoffersen, Okrągły Stół był wydarzeniem bezprecedensowym w historii grupy państw tak zwanej demokracji ludowej i dlatego z dużym żalem mówił o zmianie stosunku opozycji do wydarzeń z nim związanych i do samej idei Okrągłego Stołu. A o jego znaczeniu, a także postrzeganiu przez zachodnioniemiecką dyplomację przemian, jakie zaszły po jego kompromisowym zakończeniu, świadczy stwierdzenie Horsta Teltschika, że Polska od lata 1989 roku była już faktycznie demokratyczna ${ }^{58}$. Być może Teltschik zbyt optymistycznie ocenił stan polskiej demokracji, ale na pewno miał rację, że wówczas nasz kraj wszedł na drogę demokratyczną, bez przelewu krwi i bez większych perturbacji politycznych i społecznych, mógł być zatem przykładem dla pozostałych państw bloku wschodniego.

\section{Zakończenie}

Politycy zachodnioniemieccy, $\mathrm{w}$ tym socjaldemokraci, $\mathrm{z}$ dużym zainteresowaniem przyglądali się rozwojowi sytuacji w Polsce w 1989 roku. Korzystając z szerokiej gamy kontaktów, zarówno wśród polityków związanych z PZPR, jak i w kręgach działaczy opozycyjnych, uzyskali wgląd w działania partii oraz Solidarności. Mimo to mieli bar-

55 AdsD Koschnick 377, Erwin Kristoffersen, Internationale Abteilung, Solidarnosc und Polen die Entwicklung seit dem „Rundem Tisch”, 28. August 1990.

56 W 1989 roku doszło w bloku wschodnim do daleko idących przemian politycznych. Tutaj jako przykład można wskazać na wydarzenia w Czechosłowacji, która w latach osiemdziesiątych z dużym niepokojem patrzyła na rozwój sytuacji w Polsce (strona rządowa) i nadzieją na przemiany (opozycjoniści). Więcej zob. P. Krákora, Politické strany v Československu a listopad 1989, [w:] P. Krákora et al., Obnova demokracie $v$ Československu po roce 1989, Praha 2010, s. 113-126; T. Hubálek, Listopad 1989 z pohledu obyvatel Ústeckoorlicka, [w:] P. Krákora et al., Obnova demokracie..., s. 208-216; w tym samym tomie znajduje się również analiza przemian zachodzących w państwach Europy Środkowej: P. Kopeček, Rok 1989 ve střední Evropě, [w:] P. Krákora et al., Obnova demokracie..., s. 218-225.

57 Ibidem.

58 H. Teltschik, Gorbatschows Antwort war: Diktat, [w:] Friedliche Revolution und Demokratie. Perspektiven nach 25 Jahren, red. E. Jesse, Th. Schubert, Berlin 2015, s. 162. 
dzo poważne problemy z określeniem głównych sił politycznych na ówczesnej scenie politycznej, a przede wszystkim z określeniem przyszłego kształtu demokracji. Nie wiedziano, jak ocenić Solidarność i jej aspiracje polityczne, jakie konsekwencje dla Polski będzie miała apatia części społeczeństwa, w tym ludzi młodych. Mimo to z dużą dozą trafności uchwycili główne trendy polityczne i zagrożenia występujące wówczas na szeroko pojętej scenie politycznej. W relacjach, jakie zachowały się do dziś, przewija się przede wszystkim troska o rozwój sił postępowych w Polsce, w tym Solidarności, w której zauważalne były coraz wyraźniejsze rysy i tarcia wewnętrze spowodowane własnymi aspiracjami. Widoczna była również obawa, że nasz kraj zaprzepaści szansę, jaką dała mobilizacja społeczna początku lat osiemdziesiątych i zmiany na arenie międzynarodowej, jakie wówczas zaszły.

\section{Bibliografia}

Bingen D., Die Polenpolitik der Bonner Republik von Adenauer bis Kohl, 1949-1991, Wydawnictwo Nomos, Baden-Baden 1998.

Dudek A., Ankieta „Wolności i Solidarności”: Polski rok 1989, „Wolność i Solidarność. Studia z Dziejów Opozycji wobec Komunizmu i Dyktatury", 2014, nr 7.

Gröss A., Wandel der sowjetischen Osteuropa-Politik in der Ära Gorbatschow, P. Lang, Frankfurt am Main 1992.

Holzer J., Solidarność i iluzja społeczeństwa bezkonfliktowego, „Wolność i Solidarność. Studia z Dziejów Opozycji wobec Komunizmu i Dyktatury" 2011, nr 2, https://www.civitas.edu.pl/collegium/wp-content/uploads/2016/11/WiS_02_.pdf (dostęp: 5.10.2018).

Horst Teltschik, Geschichte der CDU, Konrad-Adenauer-Stiftung, https://www.kas.de/web/geschichte-dercdu/personen/biogramm-detail/-/content/horst-teltschik-v1 (dostęp: 3.02.2019).

Hubálek T., Listopad 1989 z pohledu obyvatel Ústeckoorlicka, [w:] Obnova demokracie v Československu po roce 1989, red. P. Krákora et al., Epocha, Praha 2010.

Kopeček P., Rok 1989 ve střední Evropě, [w:] Obnova demokracie v Československu po roce 1989, red. P. Krákora et al., Epocha, Praha 2010.

Krákora P., Politické strany v Československu a listopad 1989, [w:] Obnova demokracie v Československu po roce 1989, red. P. Krákora et al. Epocha, Praha 2010.

Nepit A., Die SED unter dem Druck der Reformen Gorbatschows: der Versuch der Parteiführung, das SEDRegime durch konservatives Systemmanagement zu stabilisieren, Wydawnictwo Nomos, Baden-Baden 2004.

Oldenburg F., Die Deutschlandpolitik Gorbatschows, 1985-1991, wyd. 17, Bundesinstitut für Ostwissenschaftliche und Internationale Studien, Köln 1992.

Pol A., Georg Waldemar Strobel (1923-2010), jego recepcja Wincentego Pola. Przyczynek selektywny do stosunków niemiecko-polskich drugiej połowy XX wieku, „Echa Przeszłości” 11, 2010.

Preuße D., Umbruch von unten. Die Selbstbefreiung Mittel- und Osteuropas und das Ende der Sowjetunion, Springer, Wiesbaden 2014.

Reiff K., Polen. Als deutscher Diplomat an der Weichsel, Dietz, Bonn 1990.

Słodkowska I., Partie i ugrupowania polityczne polskiej transformacji, [w:] Zbiorowi aktorzy polskiej polityki, red. J. Wasilewski, Instytut Studiów Politycznych PAN, Warszawa 1997, s. 31, http://www.academia. edu/16435949/Czynniki_dynamizuj\%C4\%85ce_zmiany_polskich_elit_politycznych_po_roku_1989 (dostęp: 5.10.2018). 
Strobel G.W., NSZZ „Solidarność: Beitrag zur politischen Wirkungsanalyse einer sozialen Sammlungsbewegung, „Berichte des Bundesinstituts für Ostwissenschaftliche und Internationale Studien” 1983, z. 9.

Świder M., 1989 - rok przełomu i relacje polsko-niemieckie. Wsparcie SPD dla komitetu obywatelskiego „Solidarności”, [w:] 25 lat polskiej transformacji systemowej. Dokonania i wyzwania, t. 2, red. J. Kornaś, Ł. Daniel, Wydawnictwa AGH, Kraków 2014.

Świder M., Solidarność związkowa. Niemiecka Federacja Związków Zawodowych (DGB) wobec NSZZ „Solidarność", Akademia Ignatianum w Krakowie, Kraków 2017.

Świder M., Solidarność związkowa. Zachodnioniemiecka pomoc humanitarna dla Polski (1982-1983), Wydawnictwo Naukowe Akademii Ignatianum w Krakowie, Kraków 2018.

Świder M., Stanowisko Socjaldemokratycznej Partii Niemiec wobec Polski w latach 1980-1989, Wydawnictwo Uniwersytetu Opolskiego, Opole 2015.

Teltschik H., Gorbatschows Antwort war: Diktat, [w:] Friedliche Revolution und Demokratie. Perspektiven nach 25 Jahren, red. E. Jesse, Th. Schubert, Berlin Links, Berlin 2015.

Wagensohn T., Von Gorbatschow zu Jelzin: Moskaus Deutschlandpolitik (1985-1995) im Wandel, Wydawnictwo Nomos, Baden-Baden 2000.

\section{Dokumenty źródłowe}

Archiv der sozialen Demokratie

Zespoły:

AdsD DGB-Archiv

AdsD SPD Bundestagfraktion, XI Wahlperiode

AdsD SPD Parteivorstand, Internationale Abteilung

Depozyty:

AdsD Horst Ehmke

AdsD Hans Koschnick

AdsD, Hans-Jochen Vogel

Archiwum Akt Nowych, Komitet Centralny PZPR LXXVII.

\section{Questions about Poland during the political breakthrough in 1989 through the prism of a selection of West German politicians' reports}

Keywords: Round Table, Citizens' Committee, Solidarity, trade unions, 1989 Polish legislative election, Polish political scene, West Germany

\section{Summary}

The situation in Poland at the end of 1988 as well as the dynamic changes in the first half of 1989 were a subject of many analyses in West Germany conducted by politicians and trade unionists. First of all, they were interested in the development of opposition's power and also the condition of internal reforms. On this base they tried to predict directions of the future of Polish development. In West Germany the following questions were raised: What will the Polish political scene look like? What will democracy and Solidarity be in Poland? Furthermore, West German observers were tracking political "trends" of newly created political and social organizations.

From the analysis emerges not only a picture of the country's internal division and complicated domestic relations, but also a lack of a positive programme, internal tensions and contradictory interests. In that 
crucial time, public consciousness of the importance of changes had accompanied to passivity great part of society. Foreign observers more than once expressed anxiety that Poland could miss the opportunity which arose from the citizens' mobilizations and the Solidarity movement from the beginning of the 1980s. 